\title{
Regulation of interleukin 2-dependent growth responses by glycosylphosphatidylinositol molecules
}

\author{
Isabel Merida, Joanne C. Pratt, and Glen N. Gaulton \\ Department of Pathology and Laboratory Medicine, Division of Immunobiology, University of Pennsylvania School of Medicine, Philadelphia, PA 19104
}

\begin{abstract}
The molecular mechanism of signal transduction through the interleukin 2 (IL-2) receptor remains an enigma. Glycosylphosphatidylinositol (GPI) lipids were investigated as one component of this process. IL-2 stimulated the rapid (30 sec) loss of $>50 \%$ of GPI in the IL-2-dependent T-cell line CTLL-2. Half-maximal GPI loss was detected at 40 pM IL-2, coincident with the $\mathrm{EC}_{50}(20 \mathrm{pM})$ for IL-2-induced proliferation of this cell line. This effect was specifically inhibited by antibodies that bind either IL-2 or the IL-2 receptor. The loss of GPI was mirrored by the accumulation of both polar inositolphosphoglycan (IPG) and diacylglycerol lipid fragments within cells. Increases in lipids were initially restricted to myristoyl diacylglycerol but were followed by the accumulation of myristoyl phosphatidic acid. These results are indicative of IL-2-dependent hydrolysis of GPI in T cells. The biological relevance of this hydrolysis was demonstrated by synergism of purified IPG with IL-2 in T-cell proliferation responses. The inclusion of IPG $(0.1 \mu \mathrm{M})$ in determinations of IL-2-dependent CTLL-2 growth shifted the EC $_{50}$ from 20 to 7 pM IL-2. IPG had no effect on either the number or affinity of IL-2 receptors; therefore, half-maximal CTLL-2 proliferation was obtained at $<10 \%$ IL-2 receptor occupancy. These results demonstrate that GPI lipids are an important component of the biological response to IL-2.
\end{abstract}

The lymphocytotrophic hormone interleukin 2 (IL-2) regulates the metabolism, proliferation, and differentiation of $\mathrm{T}$ lymphocytes (1-5). These events are dependent on the interaction of IL-2 with specific, high-affinity IL-2 receptors (IL-2R). The IL-2/IL-2R system is unique in that highaffinity receptors are only expressed transiently on $T$ cells as a consequence of antigen activation $(2,6)$. The high-affinity IL-2R is composed of at least two subunits, $\alpha$ (p55) and $\beta$ (p75); however, only the $\beta$ subunit is necessary for stimulating cycle progression (7-10). The results of both transfection and cross-linking studies indicate that other structurally undefined T-cell proteins are also involved in the formation of a functional IL-2R complex $(11,12)$. For example, IL-2 binding induces the activation of an IL-2R-associated tyrosine kinase (12).

IL-2-dependent regulation of cell cycle progression is primarily controlled by three variables: IL- 2 concentration, IL-2R density, and the duration of the IL-2-IL-2R interaction (3). The molecular processes that mediate these events remain unclear. Indeed, it has not been possible to definitively link IL-2R effects with any accepted signal transduction system (13). It has recently been shown that $T$ cells contain a family of glycosylphosphatidylinositol (GPI) lipids that have potent pharmacologic activities $(14,15)$. An important function of GPI relates to their putative role as second messengers of hormone action. Insulin stimulates the rapid and concentration-dependent hydrolysis of $>50 \%$ of free GPI molecules in myocytes (16), hepatoma cells (17), and T

The publication costs of this article were defrayed in part by page charge payment. This article must therefore be hereby marked "advertisement" in accordance with 18 U.S.C. $\$ 1734$ solely to indicate this fact. lymphocytes (14). The products of this reaction are inositolphosphoglycan (IPG) and diacylglycerol, indicative of the activation of endogenous GPI phospholipase C (14, 16-18). IPGs have potent insulin mimetic effects on glucose utilization $(19,20)$, alter the activities of several insulin-sensitive enzymes $(14,21-23)$, and stimulate the proliferation of insulin-dependent cell lines (24). Turnover of GPI has also been reported following nerve growth factor binding (25). These observations suggest that GPI lipids may participate in the regulation of lymphocyte metabolism and proliferation by IL-2. This hypothesis was investigated by measuring the effects of IL-2 on GPI turnover, the production of GPI metabolites, and the biological potency of GPI metabolites on T-cell proliferation.

\section{EXPERIMENTAL PROCEDURES}

Cell Culture. CTLL-2 clone G5 cells were cultured in RPMI 1640 medium (GIBCO), with $10 \%$ fetal bovine serum, penicillin/streptomycin $(100 \mu \mathrm{g} / \mathrm{ml}), 4 \mathrm{mM}$ glutamine, $50 \mu \mathrm{M}$ 2-mercaptoethanol, and recombinant IL-2 (10 units/ml) (Amgen Biologicals). Proliferation of CTLL-2 cells in response to IL-2 (0-1 $\mathrm{nM})$ was determined by $\left[{ }^{3} \mathrm{H}\right]$ thymidine incorporation after a $24-\mathrm{hr}$ incubation as described (26). In some instances, IL-2 proliferation assays were conducted with the addition of purified IPG $(0.1 \mu \mathrm{M})$ or mock IPG preparation (equal volume) as described below. IL-2 binding assays were conducted with ${ }^{125}$ I-labeled recombinant IL-2 $\left(2.2 \times 10^{6}\right.$ $\mathrm{cpm} / \mathrm{pmol} ; \mathrm{NEN})$ as described $(2,6)$. Where indicated in the text, cells were labeled with either $2.5 \mu \mathrm{Ci}$ of $\left[6^{-3} \mathrm{H}\right]$ glucosamine hydrochloride per $\mathrm{ml}(33 \mathrm{Ci} / \mathrm{mmol} ; 1 \mathrm{Ci}=37 \mathrm{GBq}$; Amersham), $10 \mu \mathrm{Ci}$ of myo- $\left[1-{ }^{3} \mathrm{H}\right]$ inositol per $\mathrm{ml}(16.3 \mathrm{Ci} /$ mmol; Amersham), $5.0 \mu \mathrm{Ci}$ of $\left[9,10-{ }^{3} \mathrm{H}\right]$ myristic acid per $\mathrm{ml}$ $(22.4 \mathrm{Ci} / \mathrm{mmol}$; NEN), or $1.0 \mu \mathrm{Ci}$ of $[5,6,8,9,11,12,14,15$ ${ }^{3} \mathrm{H}$ ]arachidonic acid per $\mathrm{ml}(238 \mathrm{mCi} / \mathrm{mmol}$; NEN). The integrity of radiolabels following metabolic incorporation was evaluated by TLC analysis of the products of either acid (for sugars) or base (for fatty acids) hydrolysis of putative GPI as described (14). Fidelity was $>94 \%$ for each label. The DMS-1 hybridoma (anti-IL-2) was generously provided by $\mathbf{K}$. Smith (Dartmouth College). The M7/20 hybridoma (anti-IL$2 \mathrm{R} \alpha$ ) was prepared as described (27).

Lipid Isolation and Analysis. CTLL-2 cells were serum starved for $2 \mathrm{hr}$ in IL-2-free RPMI 1640 medium prior to all lipid assays. IL-2-free media contained only RPMI 1640 medium in $1 \%$ ultrapure bovine albumin (Boehringer Mannheim). Aliquots of $5 \times 10^{6}$ labeled cells were incubated with IL-2 (0-1 nM) for 0-60 min. At the conclusion of incubations, cells were washed twice in $20 \mathrm{mM} \mathrm{NaH} \mathrm{PO}_{4} / \mathrm{Na}_{2} \mathrm{HPO}_{4} / 150$ $\mathrm{mM} \mathrm{NaCl}$ and incubated with an equal volume of $10 \%$ cold trichloroacetic acid (TCA). Lipids were extracted from the resultant TCA pellets by addition of chloroform/methanol/ $\mathrm{HCl}$ (1:2:0.004), followed by chloroform/0.1 M KCl (1:1),

Abbreviations: IL-2, interleukin 2; IL-2R, IL-2 receptor; GPI, glycosylphosphatidylinositol; IPG, inositolphosphoglycan; PI, phosphatidylinositol; PI-PLC, PI-specific phospholipase C. 
Table 1. Hydrolysis of lymphocyte GPI

\begin{tabular}{lcc} 
& \multicolumn{2}{c}{$\%$ aqueous } \\
& \multicolumn{2}{c}{ conversion } \\
\cline { 2 - 3 } \multicolumn{1}{c}{ Treatment } & GPI & PI \\
\hline PI-PLC (B. thuringiensis) & $85^{*}$ & $93^{*}$ \\
PI-PLC (human T cell) & $86^{*}$ & $94^{*}$ \\
PI-PLC (buffer control) & 4 & 3 \\
Sodium nitrite (pH 3.75) & $78^{*}$ & 5 \\
Sodium chloride (pH 3.75) & 5 & 6 \\
\hline
\end{tabular}

Lipids were purified from CTLL-2 cells radiolabeled with $\left[{ }^{3} \mathrm{H}\right] \mathrm{i}-$ nositol and incubated with PI-PLC (1 unit $/ \mathrm{ml}), \mathrm{HNO}_{2}(0.33 \mathrm{M})$, or controls. Results are presented as the means of triplicate experiments and are expressed as percentage initial label that was recovered in the aqueous phase after treatment and extraction.

$* P<0.001$ by Student's $t$ test in comparison to controls.

and finally methanol/0.2 $\mathrm{M} \mathrm{KCl}(1: 1)$ as described $(14,17)$. GPI lipids were then purified by sequential separations on TLC (14). Briefly, GPI lipids were first separated from the major acidic phospholipids by banding on silica gel G TLC plates (EM Science) run in the solvent system chloroform/ acetone/methanol/glacial acetic acid/water (50:20:10:10:5). Lipids were extracted from silica in methanol and reapplied to a second silica plate developed in the solvent system chloroform/methanol/ $\mathrm{NH}_{4} \mathrm{OH} /$ water (45:45:3.5:10), which enabled separation of GPI from phosphatidylinositol (PI), phosphatidylinositol 4-phosphate, and phosphatidylinositol 4,5-bisphosphate. Diacylglycerol levels were determined by TLC separation in the solvent hexane/diethyl ether/acetic acid (70:30:1). Levels of phosphatidic acid were determined by using the solvent ethyl acetate/isooctane/acetic acid/ water (90:50:20:100).

Sensitivity to PI-specific phospholipase C (PI-PLC) was determined in the presence of PI-PLC purified from Bacillus thuringiensis (1 unit/ml; ICN) or an enriched PI-PLC extract isolated from human $\mathrm{T}$ cells $(1 \mathrm{unit} / \mathrm{ml})$ in $25 \mathrm{mM}$ Hepes, $\mathrm{pH}$ $7.4 / 100 \mu \mathrm{M} \mathrm{CaCl}_{2}$ for $30 \mathrm{~min}$ at $37^{\circ} \mathrm{C}$ (14). It is not currently possible to distinguish PI versus GPI specificity of the T-cell lipase preparation. Sensitivity to nitrous acid was determined by incubation in $50 \mathrm{mM}$ sodium acetate/0.33 M sodium

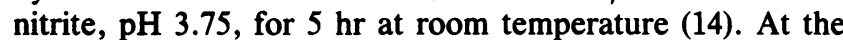
conclusion of these reactions, the aqueous and organic soluble products were separated by extraction in chloroform/ methanol (2:1) and aqueous counts were determined. IPGs were isolated from the aqueous-phase extracts of PI-PLCtreated GPI. GPIs were purified from human T lymphocytes as described above. IPGs were quantified by phosphate content based on the assumption of one phosphate residue per molecule (14). Purified IPG (10 ng) was derived from $5 \times$
$10^{8} \mathrm{~T}$ cells. IPGs were first separated from uncleaved GPI, then purified on an analytical Partisil 10 SAX HPLC column eluted in a linear gradient of $20 \mathrm{mM}-1 \mathrm{M}$ triethylamine formate (pH 4.5) at $1 \mathrm{ml} / \mathrm{min}$ as described (25). $\left[{ }^{3} \mathrm{H}\right]$ Inositol eluted as a single peak at $15 \mathrm{~min} .\left[{ }^{3} \mathrm{H}\right]$ Glucosamine eluted as a doublet at 15 (major peak) and 18 (minor peak) min. IL-2 augmented label in only the 15 -min peak. Purification and quantitation of IPG was, therefore, based only on material from the 15-min elution point. Purified IPGs were extensively lyophilized and redissolved in $25 \mathrm{mM}$ Hepes, $\mathrm{pH} 7.4 / 50 \mathrm{mM}$ $\mathrm{NaCl}$ prior to biological assays. Mock IPG preparations were the aqueous reaction products of PI-PLC incubations with PI treated in an identical manner.

\section{RESULTS}

IL-2-Dependent Hydrolysis of GPI. GPI lipids were isolated from CTLL-2 cells by organic extraction and preparative TLC. Contamination of these lipids by any of the inositol phospholipids or other acidic phospholipids was $<5 \%$ as determined by reanalysis on high-performance TLC. The purity and predicted core structure of GPI lipids isolated in a similar manner from hepatocytes have also been confirmed by mass spectrometry (28). Lipid purity was further assessed by sensitivity to digestion with PI-PLC and deamination with $\mathrm{HNO}_{2}$. Hydrolysis in response to both of these agents is diagnostic of GPI. Treatment of GPI with PI-PLC isolated from either $B$. thuringiensis or human peripheral blood T cells stimulated the hydrolysis of $>80 \%$ of lymphocyte GPI and $>90 \%$ of PI (Table 1). Similar treatment with $\mathrm{HNO}_{2}$ resulted in $73 \%$ hydrolysis of GPI, with no corresponding hydrolysis of PI. The specificity of these reactions was verified by the detection of diacylglycerol and PI in the organic extracts of PI-PLC and $\mathrm{HNO}_{2}$ incubations, respectively (data not shown).

IL-2-dependent hydrolysis of GPI was measured in CTLL-2 cells by recovery of radiolabeled GPI after IL-2 binding. Cells were labeled metabolically with $\left[{ }^{3} \mathrm{H}\right]$ glucosamine and then incubated with a receptor saturating dose of IL-2 (1 nM) for 0-5 min. GPI lipids were isolated from these reactions by sequential acid/base TLC and quantitated. As shown in Fig. $1 A$, GPI molecules displayed a biphasic response to IL-2. Approximately $55 \%$ of total cellular GPI was lost within $30 \mathrm{sec}$ of IL-2 binding. GPI levels then increased briefly to $>75 \%$ of original levels but declined thereafter, such that by 5 min only $28 \%$ of GPI remained. An identical pattern of GPI turnover was observed in $\left[{ }^{3} \mathrm{H}\right]$ inositol-labeled cells. There was no change in GPI levels of CTLL-2 cells treated with IL-2 diluent. Hydrolysis of GPI in response to IL-2 binding was verified by recovery of the polar $\left[{ }^{3} \mathrm{H}\right]$ glucosamine-IPG fragment in the

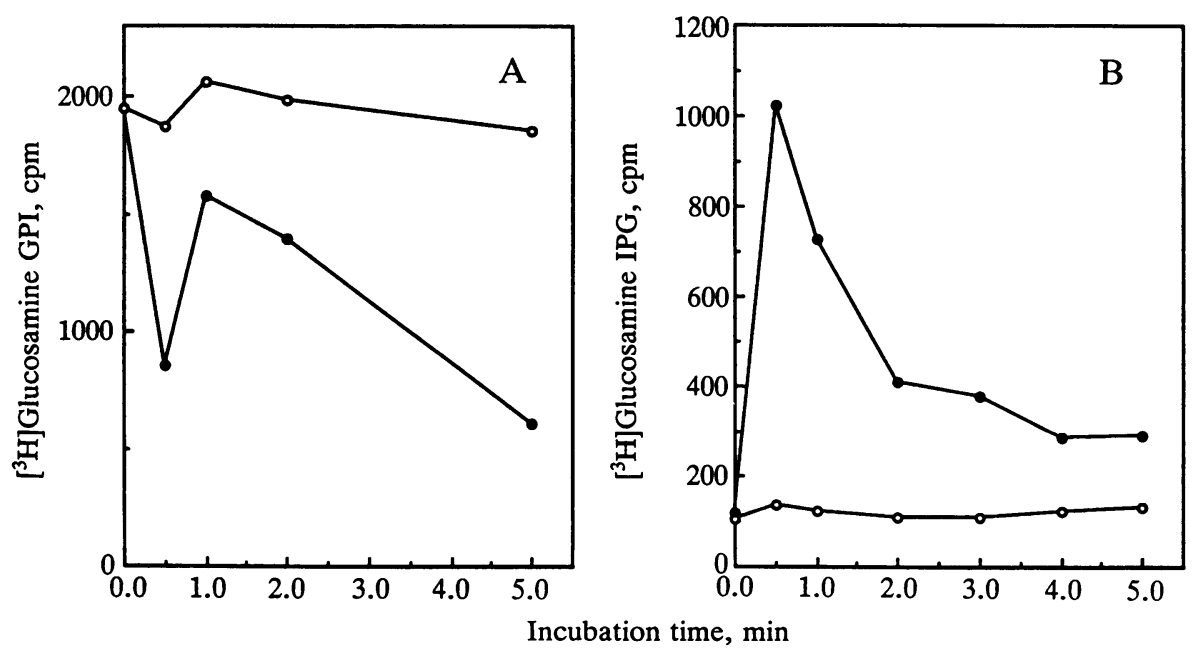

Fig. 1. Time course of IL-2dependent hydrolysis of GPI in CTLL-2 cells. CTLL-2 cells were prelabeled with $\left[{ }^{3} \mathrm{H}\right]$ glucosamine $(2.5$ $\mu \mathrm{Ci} / \mathrm{ml}$ ) for $36 \mathrm{hr}$ prior to assay. Metabolically labeled cells were serum starved in IL-2-free medium for $2 \mathrm{hr}$ and then stimulated by addition of 1 nM IL-2 (๑) or buffer alone (O). At the times indicated, cells were extracted for GPI or IPG determinations. $(A)$ GPI levels in the organic phase extracts quantified by sequential TLC. $(B)$ IPG levels in the aqueous phase of GPI extractions quantified by SAX HPLC. 

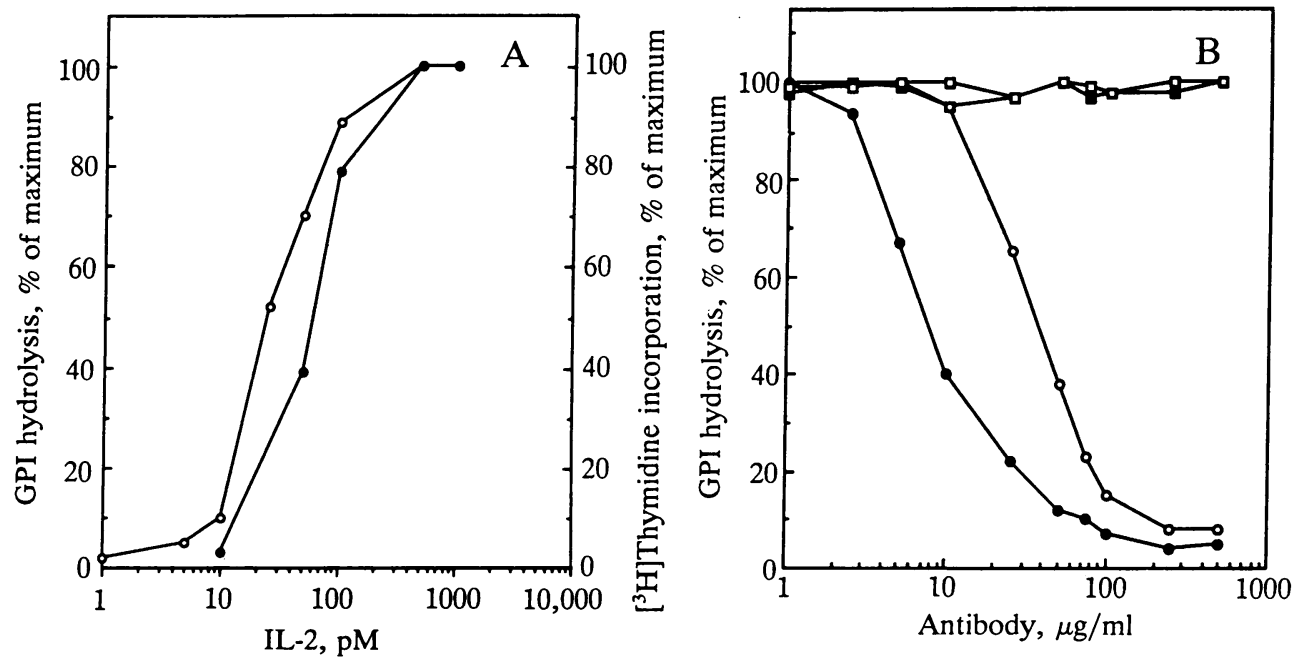

FIG. 2. Dose-response and specificity of IL-2-induced GPI hydrolysis in CTLL-2 cells. $(A)$ Dose dependence of IL-2 on GPI hydrolysis ( $\bullet$ ) and proliferation of CTLL-2 cells (O). GPI hydrolysis was determined in cells labeled with $\left[{ }^{3} \mathrm{H}\right]$ glucosamine as indicated in Fig. 1 . IL-2 (0-10,000 pM) was added at $37^{\circ} \mathrm{C}$ and reactions were terminated after $30 \mathrm{sec}$ by organic extraction. GPI levels were determined by TLC analysis. Results are expressed as a percentage of maximal GPI hydrolysis; $100 \%$ loss corresponded to $63 \%(1805 \mathrm{cpm})$ total GPI hydrolysis. The proliferation of CTLL-2 cells in response to IL-2 is expressed as a percentage of the maximum incorporation of [ $\left.{ }^{3} \mathrm{H}\right]$ thymidine into the cells during a 4-hr pulse after $20 \mathrm{hr}$ of culture; $100 \%$ incorporation corresponded to $27,432 \mathrm{cpm}$. (B) Specificity of IL-2-induced GPI hydrolysis. Cells were labeled with $\left.{ }^{3} \mathrm{H}\right]$ glucosamine as described above and stimulated with $500 \mathrm{pM}$ IL-2 in the presence of increasing concentrations of purified antibody DMS-1 (๑), M7/20 (O), murine IgG1 control ( $\square$ ), or rat IgM control ( $\square$ ). After $30 \mathrm{sec}$, the cells were extracted and the level of GPI was quantified by TLC as described. Results are expressed as percentage of maximum hydrolysis; $100 \%$ loss corresponded to $66 \%$ (2258 cpm) total GPI hydrolysis.

aqueous-phase extracts of these same cells by using SAX HPLC (Fig. 1B). The levels of IPG increased $\approx 10$-fold within 30 sec of IL-2 binding, coincident with the early loss of GPI. IPG levels then declined gradually without evidence of a biphasic response during the second-phase GPI loss at 2-5 min.

The proliferative effects of IL-2 demonstrate a strict dose dependence that correlates with the $K_{\mathrm{d}}$ of the high-affinity IL-2R $(2,29)$. A similar analysis of IL-2 dose dependence of GPI hydrolysis was conducted and is presented in Fig. $2 A$. Half-maximal proliferation $\left(\mathrm{EC}_{50}\right)$ of CTLL-2 cells was observed at $20 \mathrm{pM}$ IL-2, which is very close to the $K_{\mathrm{d}}(18 \mathrm{pM})$ of IL-2 in this cell line (ref. 13; see also Fig. 5). The half-maximal effect of GPI hydrolysis occurred at $40 \mathrm{pM}$ IL-2 in good agreement with the $\mathrm{EC}_{50}$ for proliferation. The specificity of IL-2-dependent hydrolysis was further investigated by determining the effects of antibodies that bind either IL-2 (hybridoma DMS-1) or IL-2R $\alpha$ (hybridoma M7/ 20) on GPI levels. Both of these antibodies inhibit the binding and proliferative effects of IL-2 $(27,29)$. Results presented in Fig. $2 B$ illustrate that IL-2-dependent GPI hydrolysis was completely inhibited at DMS-1 and M7/20 antibody concentrations $>100 \mu \mathrm{g} / \mathrm{ml}$. The addition of isotype-matched antibody controls did not affect GPI hydrolysis at any dosage tested.

IL-2-Dependent Production of Diacylglycerol and Phosphatidic Acid. The hydrolysis of GPI by PI-PLC results in the production of IPG and diacylglycerol (16-18). IL-2dependent accumulation of diacylglycerol has been reported (30); however, this is not derived from the turnover of PI (31). IL-2-dependent hydrolysis of GPI provides an explanation for these results. The production of diacylglycerol in response to IL-2, shown in Fig. 3, was measured in CTLL-2 cells that were labeled metabolically with either $\left[{ }^{3} \mathrm{H}\right]$ myristate or $\left[{ }^{3} \mathrm{H}\right]$ arachidonate. Myristate was previously shown to be preferentially incorporated into T-cell GPI (14). In contrast, arachidonate and stearate are abundant in the inositol phospholipids and other major acidic phospholipids of T cells $(25,32)$. Incubation with IL-2 $(1 \mathrm{nM})$ resulted in the rapid accumulation of $\left[{ }^{3} \mathrm{H}\right]$ myristate-labeled diacylglycerol at $30 \mathrm{sec}$, coincident with both GPI hydrolysis and the accu- mulation of IPG (Fig. 1). There was no change in the level of $\left[{ }^{3} \mathrm{H}\right]$ arachidonate-labeled diacylglycerol under these same conditions.

Il-2-induced changes in lipid metabolism were not limited to diacylglycerol. IL-2 was also shown to affect the cellular pool of phosphatidic acid (Fig. 4). Increases in $\left[{ }^{3} \mathrm{H}\right]$ myristatelabeled phosphatidic acid lagged $30 \mathrm{sec}$ to $1 \mathrm{~min}$ behind those of diacylglycerol but followed the same overall pattern of accumulation and decay. There were no changes in the level of incorporation of $\left[{ }^{3} \mathrm{H}\right]$ arachidonate into phosphatidic acid with IL-2 treatment. This suggests that increases in phosphatidic acid were generated by phosphorylation of newly released diacylglycerol rather than by either de novo synthesis of phosphatidic acid or through hydrolysis of GPI by phospholipase D.

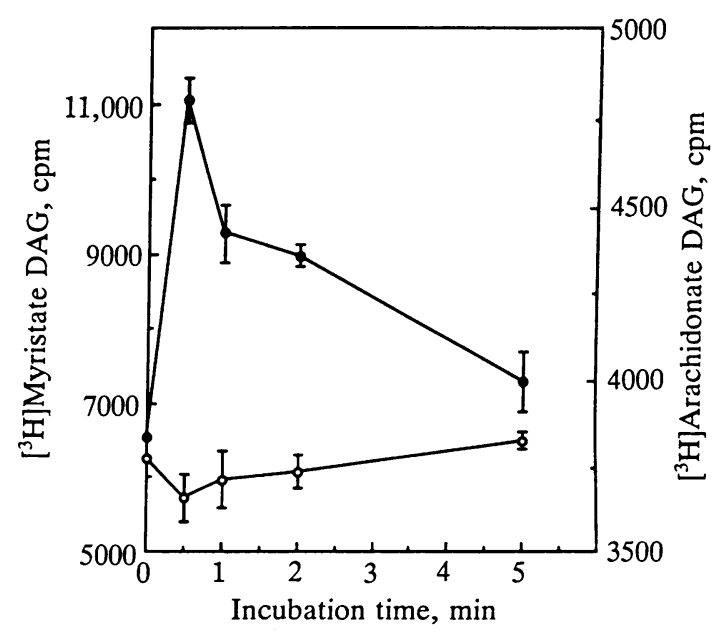

FIG. 3. IL-2-induced diacylglycerol (DAG) production in CTLL-2 cells. Cells were incubated for $24 \mathrm{hr}$ with $\left[{ }^{3} \mathrm{H}\right]$ myristic acid at $5 \mu \mathrm{Ci} / \mathrm{ml}(\bullet)$ or $\left[{ }^{3} \mathrm{H}\right]$ arachidonic acid at $1 \mu \mathrm{Ci} / \mathrm{ml}(0)$ and then washed into IL-2-free medium and stimulated with $1 \mathrm{nM}$ IL-2 for 0-5 $\mathrm{min}$. Cells were extracted at the times indicated and labeled diacylglycerol was quantified by TLC. Results represent the mean \pm SE of triplicate samples. 


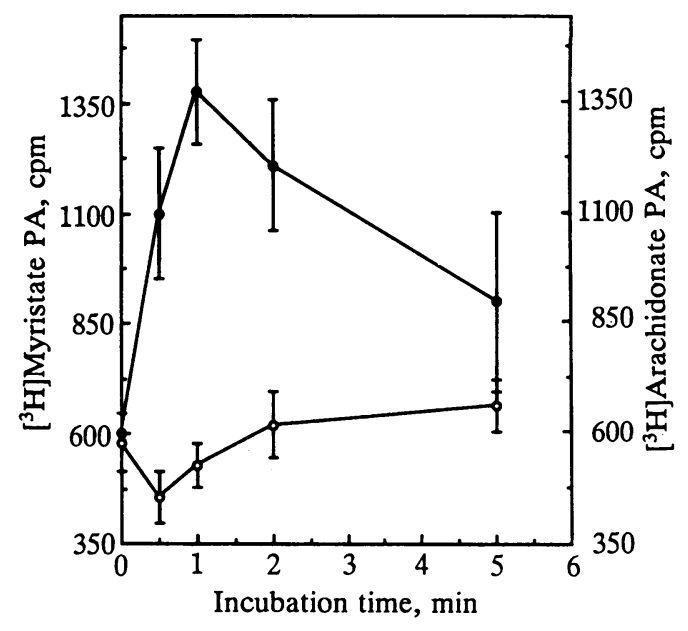

FIG. 4. IL-2-induced phosphatidic acid (PA) production in CTLL-2 cells. Cells were incubated for $24 \mathrm{hr}$ with $\left[{ }^{3} \mathrm{H}\right]$ myristic acid at $5 \mu \mathrm{Ci} / \mathrm{ml}(\bullet)$ or $\left[{ }^{3} \mathrm{H}\right]$ arachidonic acid at $1 \mu \mathrm{Ci} / \mathrm{ml}(0)$ and then washed into IL-2-free medium and stimulated with $1 \mathrm{nM}$ IL-2 for 0-5 $\mathrm{min}$. Cells were extracted at the times indicated and labeled phosphatidic acid was quantified by TLC. Results represent the mean \pm SE of triplicate samples.

Regulation of T-Cell Growth by IPG. IPGs are potent regulators of the metabolism and growth of adipocytes, hepatocytes, and myocytes (19-23). The importance of IPG in T-cell growth responses to IL-2 was investigated by measuring the effects of IPG $(0.1 \mu \mathrm{M})$ on IL-2-dependent growth response curves. As shown in Fig. $5 A$ the presence of IPG shifted the IL-2 growth curve from an $\mathrm{EC}_{50}$ of 20 to $7 \mathrm{pM}$. There was no effect of IPG alone, at this dose, on T-cell proliferation. One explanation for this effect is that IPG alters either the number or the affinity of IL-2R. Direct binding experiments were conducted with ${ }^{125} \mathrm{I}$-labeled recombinant IL-2 on both untreated and IPG-treated CTLL-2 cells. Results presented in Fig. $5 B$ illustrate that there was no difference in any parameters of IL-2 binding under these two conditions. CTLL-2 cells expressed 2600 high-affinity $\left(K_{d}=\right.$ $18 \mathrm{pM})$ and 470,000 low-affinity $\left(K_{\mathrm{d}}=12 \mathrm{nM}\right)$ receptors, in agreement with previous data $(6,13)$. The effect of IPG on
IL-2-induced proliferation thus results in half-maximal proliferation at $<10 \%$ receptor occupancy by IL- 2 .

\section{DISCUSSION}

The interaction between IL-2 and its high-affinity receptor is one of the most exquisitely controlled of all mammalian growth factor systems. However, despite significant advances in the structural and functional characterization of IL-2 and the IL-2R, the molecular processes that govern IL-2R signal transduction remain largely undefined. Some clues to this process have come from the recent observation that IL-2 binding activates a receptor-associated tyrosine kinase (12). Previous analyses failed to reproducibly detect PI hydrolysis or $\mathrm{Ca}^{2+}$ flux as components of this response, although increases in diacylglycerol were observed $(30,31$, 33). Studies reported here were initiated to improve our understanding of IL-2R signaling responses and of the multiple roles of IL-2 in the regulation of lymphocyte metabolism, differentiation, and proliferation. These results demonstrate that binding of high-affinity IL-2R stimulates the rapid hydrolysis of GPI, with coordinate intracellular accumulation of IPG and diacylglycerol moieties.

It is hypothesized that GPI metabolites mediate some of the biological effects of IL-2. Results from studies with insulinresponsive cells have shown that IPGs are potent regulators of the activities of several enzymes that control cellular metabolic function. This may occur through alterations in the levels of phosphorylation and dephosphorylation of specific protein substrates $(23,34)$. For example, IPGs were shown to inhibit the phosphorylation of phospholipid methyltransferase and thereby to block isoproterenol-induced activation (23). The addition of IPG was also shown to directly increase glucose utilization and lipogenesis in adipocytes (19). Although the structure of IPG has not been completely deduced, these molecules contain inositol phospholipid glycosidically linked to non- $\mathrm{N}$-acetylated glucosamine and from two to four hexose units that may include mannose and galactose (28).

The relationship between the regulation of lymphocyte metabolism and proliferation has not been carefully studied. IL-2 has been shown to increase both aerobic and anaerobic lymphocyte metabolism, and it is required for maintenance of
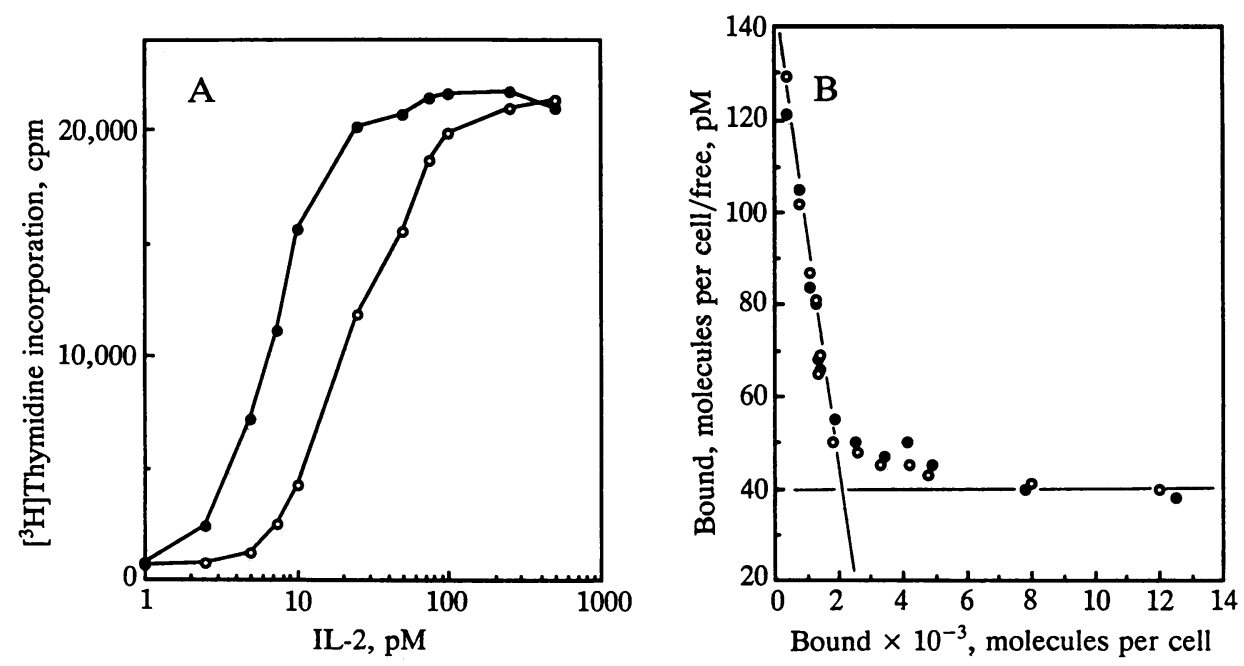

FIG. 5. Effect of IPG on IL-2-induced cell proliferation and IL-2 binding. ( $A$ ) Proliferation of CTLL-2 cells in response to IL-2 was determined by $\left[{ }^{3} \mathrm{H}\right]$ thymidine incorporation. Incubations were conducted in the presence of either IL-2 (0-500 pM) and IPG $(0.1 \mu \mathrm{M})(\bullet)$ or IL-2 and an equal volume of mock IPG preparation $(0)$. (B) The affinity and number of CTLL-2 cell-surface receptors for IL-2 were determined by binding of 125 I-labeled recombinant IL-2 as described $(6,13)$. Cells were examined for receptor parameters after a 24 -hr preincubation with either 500 pM IL-2-IPG $(0.1 \mu \mathrm{M})(\bullet)$ or 500 pM IL-2-mock IPG (0) as described in proliferation assays. Saturation binding data were evaluated by Scatchard analysis. 
the viability of T-cell lines such as CTLL-2 (1). The ability of IPG to synergize with IL-2 to promote T-cell proliferation at low receptor occupancy indicates that IPGs are an important component of T-cell growth responses. This may be a consequence of increased energy production through aerobic oxidation and/or increased production of precursors for macromolecule biosynthesis that are prerequisite to cellular proliferation. Studies on the direct effects of IPG on T-cell metabolism should help to distinguish the metabolic effects of IL-2 from those of proliferation and differentiation.

IL-2-dependent increases in $\left[{ }^{3} \mathrm{H}\right]$ myristate versus $\left[{ }^{3} \mathrm{H}\right]$ arachidonate diacylglycerol are indicative of GPI hydrolysis rather than either de novo diacylglycerol synthesis or the breakdown of other phospholipid species. The biological role of increased diacylglycerol levels is unclear. It has been established that activation of protein kinase $\mathrm{C}$ is not obligatory for IL-2 proliferative effects $(35,36)$. The presence of distinctive, short chain unsaturated fatty acids such as myristate in GPI may, however, target these lipids for regulation of specific enzyme pathways. In addition, increases in phosphatidic acid have been shown to have potent effects on cellular metabolism in several systems (37).

IL-2-dependent hydrolysis of GPI displays a distinctive biphasic pattern. This is contrasted to previous reports of insulin and nerve growth factor-stimulated GPI hydrolysis in several cell types, including lymphocytes $(14,16-18,25)$. While the early loss of GPI can be attributed to IL-2stimulated hydrolysis, the subsequent decay of GPI at 2-5 min may reflect either hydrolysis or the partitioning of GPI to inextractable cellular pools. The latter model appears more likely based on the kinetics of IPG, diacylglycerol, and phosphatidic acid production and decay. In addition to their putative roles as hormone signaling elements, GPI molecules serve an important function in eukaryotic cells as membrane anchors for a large family of proteins (15). Studies on the synthesis of the GPI-anchored protein Thy-1 indicated that protein coupling to lipid occurred within seconds after translation (38). This indicates that a considerable proportion of GPI may be destined for protein biosynthesis rather than hormone response elements (39). The second phase loss of GPI might therefore reflect increased recruitment of cellular GPI pools to biosynthesis of lipid-anchored proteins. Direct examination of the effect of IL-2 on the synthesis and membrane insertion of GPI-anchored proteins and their potential roles in lymphocyte growth remains to be investigated.

G.N.G. is a H. Weaver neuroscience scholar of the National Multiple Sclerosis Society. This work was supported by the W. W. Smith Foundation, the Lucille B. Markey Trust, Grant RO1 AI25535 from the National Institutes of Health, and a postdoctoral award to I.M. from the Ministerio de Education y Ciencia in Spain.

1. Maddock, E. O., Maddock, S. W., Kelley, V. E. \& Strom, T. B. (1985) J. Immunol. 135, 4004-4008.

2. Cantrell, D. A. \& Smith, K. A. (1983) J. Exp. Med. 158, 1895-1911.

3. Cantrell, D. A. \& Smith, K. A. (1984) Science 224, 1312-1316.

4. Gillis, S. \& Watson, J. (1981) J. Immunol. 126, 1245-1248.

5. Howe, R. C., Milstone, D. S., Ratliff, T. L. \& Russell, J. H. (1985) J. Immunol. 134, 2414-2418.

6. Robb, R. J., Munck, A. \& Smith, K. A. (1981) J. Exp. Med. 154, 1455-1474.

7. Leonard, W. J., Depper, J. M., Uchiyama, T., Smith, K. A.,
Waldman, T. A. \& Greene, W. C. (1982) Nature (London) 300, 267-269.

8. Sharon, M., Klausner, R. D., Cullen, B. R., Chizzonite, R. \& Leonard, W. J. (1986) Science 234, 859-863.

9. Teshigawa, K., Wang, H.-M., Kato, K. \& Smith, K. A. (1987) J. Exp. Med. 165, 223-238.

10. Wang, H.-M. \& Smith, K. A. (1987) J. Exp. Med. 166, 10551069.

11. Sabe, H., Kondo, S., Shimizu, A., Tagaya, Y., Yodoi, J., Kobayashi, N., Hatanaka, M., Matsunami, N., Maeda, M., Noam, T. \& Honjo, T. (1984) Mol. Biol. Med. 2, 379-396.

12. Merida, I. \& Gaulton, G. N. (1990) J. Biol. Chem. 265, 56905694.

13. Tigges, M. A., Casey, L. S. \& Koshland, M. E. (1989) Science 243, 781-786.

14. Gaulton, G. N., Kelly, K. L., Pawlowski, J., Mato, J. M. \& Jarett, L. (1988) Cell 53, 963-970.

15. Low, M. G. \& Saltiel, A. R. (1988) Science 239, 268-275.

16. Saltiel, A. R., Fox, J. A., Sherline, P. \& Cuatrecasas, P. (1986) Science 233, 967-972.

17. Mato, J. M., Kelly, K. L., Abler, A. \& Jarett, L. (1987) J. Biol. Chem. 262, 2131-2137.

18. Saltiel, A. R., Sherline, P. \& Fox, J. A. (1987) J. Biol. Chem. 262, 1116-1121.

19. Saltiel, A. R. \& Sorbara-Cazan, L. (1987) Biochem. Biophys. Res. Commun. 149, 1084-1092.

20. Kelly, K. L., Mato, J. M., Merida, I. \& Jarett, L. (1987) Proc. Natl. Acad. Sci. USA 84, 6404-6407.

21. Villalba, M., Kelly, K. L. \& Mato, J. M. (1988) Biochim. Biophys. Acta 968, 69-76.

22. Saltiel, A. R. (1987) Endocrinology 120, 967-972.

23. Kelly, K. L., Merida, I., Wong, E. H. A., DiCenzo, D. \& Mato, J. M. (1987) J. Biol. Chem. 262, 15285-15291.

24. Witters, L. A. \& Watts, T. D. (1988) J. Biol. Chem. 264, 757-766.

25. Chan, B. L., Chao, M. V. \& Saltiel, A. R. (1989) Proc. Natl. Acad. Sci. USA 86, 1756-1760.

26. Gillis, S., Ferm, M. M., Ou, W. \& Smith, K. A. (1978) J. Immunol. 120, 2027-2031.

27. Gaulton, G. N., Bangs, J., Maddock, S., Springer, T., Eardley, D. D. \& Strom, T. B. (1985) Clin.Immunol. Immunopathol. 36, 18-29.

28. Mato, J. M., Kelly, K. L., Abler, A., Jarett, L., Corkey, B. E., Cashel, J. A. \& Zopf, D. (1987) Biochem. Biophys. Res. Commun. 146, 764-770.

29. Smith, K. A., Favata, M. F. \& Oroszlan, S. (1983) J. Immunol. 131, 1808-1815.

30. Farrar, W., Cleveland, J., Beckner, S., Bonvini, E. \& Evans, S. (1986) Immunol. Rev. 92, 49-65.

31. Mills, G., Stewart, D., Mellors, A. \& Gelfand, E. (1986) J. Immunol. 136, 3019-3025.

32. Rosoff, P. M., Savage, N. \& Dinarello, C. A. (1988) Cell 54, 73-81.

33. Mills, G., Cheung, R., Grinstein, S. \& Gelfand, E. (1985) J. Immunol. 134, 2431-2435.

34. Alemany, S., Mato, J. M. \& Stralfors, P. (1987) Nature (London) 330, 77-79.

35. Mills, G. B., Girard, P., Grinstein, S. \& Gelfand, E. W. (1988) Cell 55, 91-100.

36. Valge, V. E., Wong, J. G. P., Datlof, B. M., Sinskey, A. J. \& Roa, A. (1988) Cell 55, 101-112.

37. Bocckino, S. B., Blackmore, P. F., Wilson, P. B. \& Exton, J. H. (1987) J. Biol. Chem. 262, 15309-15315.

38. Conzelmann, A., Spiazzi, A. \& Bron, C. (1987) Biochem. J. 246, 605-610.

39. Krakow, J. L., Hereld, D., Bangs, J. D., Hart, G. W. \& Englund, P. T. (1989) J. Biol. Chem. 261, 12147-12153. 